\title{
Stress and Glucocorticoids Affect the Expression of Brain-Derived Neurotrophic Factor and Neurotrophin-3 mRNAs in the Hippocampus
}

\author{
Mark A. Smith, ${ }^{1}$ Shinya Makino, ${ }^{2}$ Richard Kvetnansky, ${ }^{3}$ and Robert M. Post ${ }^{1}$ \\ ${ }^{1}$ Biological Psychiatry and ${ }^{2} \mathrm{Clinical}$ Neuroendocrinology Branches, National Institute of Mental Health, Bethesda, \\ Maryland 20892 and ${ }^{3}$ Institute of Experimental Endocrinology, Slovak Academy of Sciences, Bratislava, Slovakia
}

\begin{abstract}
Chronic stress produces structural changes and neuronal damage especially in the hippocampus. Because neurotrophic factors affect neuron survival, we questioned whether they might be relevant to the heightened vulnerability of hippocampal neurons following stress. To begin investigating this possibility, we examined the effects of immobilization stress ( $2 \mathrm{hr} / \mathrm{d}$ ) on the expression of neurotrophic factors in rat brains using in situ hybridization. We found that single or repeated immobilization markedly reduced brain-derived neurotrophic factor (BDNF) mRNA levels in the dentate gyrus and hippocampus. In contrast, NT-3 mRNA levels were increased in the dentate gyrus and hippocampus in response to repeated but not acute stress. Stress did not affect the expression of neurotrophin-4, or tyrosine receptor kinases (trkB or $\mathrm{C}$ ). Corticosterone negative feedback may have contributed in part to the stressinduced decreases in BDNF mRNA levels, but stress still decreased BDNF in the dentate gyrus in adrenalectomized rats suggesting that additional components of the stress response must also contribute to the observed changes in BDNF. However, corticosterone-mediated increases in NT-3 mRNA expression appeared to be primarily responsible for the effects of stress on NT-3. These findings demonstrate that BDNF and NT-3 are stress-responsive genes and raise the possibility that alterations in the expression of these or other growth factors might be important in producing some of the physlological and pathophysiological effects of stress in the hippocampus.
\end{abstract}

[Key words: stress, brain-derived neurotrophic factor, neurotrophin-3, hippocampus, glucocorticoids, plasticity]

Chronic stress produces deleterious effects in the brain just as it does in other body organs (Johnson et al., 1992). For instance, repeated stress or high levels of glucocorticoids decrease the number of apical dendrite branch points (Wooley et al., 1990; Watanabe et al., 1992) and produce cell loss (Sapolsky, 1992) in the CA3 pyramidal layer of the hippocampus. Neuronal damage in the hippocampus can be seen in monkeys subjected to social stress in the wild (Uno et al., 1989). Moreover, glucocor-

\footnotetext{
Received Feb. 24, 1994; revised Aug. 12, 1994; accepted Sept. 1, 1994

These data were presented in part at the 23rd Annual Meeting of the Society for Neuroscience in Washington, DC, 1993.

Correspondence should be addressed to Dr. Mark A. Smith, Biological Psy chiatry Branch, National Institute of Mental Health, Building 10, Room 3N212, 9000 Rockville Pike, Bethesda, MD 20892.

Copyright $(C) 1995$ Society for Neuroscience $0270-6474 / 95 / 151768-10 \$ 05.00 / 0$
}

ticoids hasten the loss of hippocampal neurons that normally occurs during aging (Landfield, 1987). As the hippocampus is important in cognitive processes such as learning and memory, neuronal damage to this structure may be linked to the cognitive impairments that occur during aging and chronic stress.

Aside from the role of glucocorticoids, exactly how chronic stress causes neuronal damage is unclear. Glucocorticoids, although not directly toxic themselves, inhibit glucose transport in hippocampal neurons making them vulnerable to a wide variety of insults such as kainic acid seizures and metabolic toxins (Sapolsky, 1986; Sapolsky, 1992). The effects of glucocorticoids are anatomically selective, and in contrast to the damage they cause in the hippocampus, glucocorticoids are apparently necessary for the maintenance of dentate gyrus granule neurons (Sloviter et al., 1989).

Because neurotrophic factors are necessary for the normal development, survival, and plasticity of neurons, we reasoned that they too might be relevant to the neuropathological effects of chronic stress. In addition to NGF, several related neurotrophic factors have been recently characterized including brain-derived neurotrophic factor (BDNF) (Leibrock et al., 1989), neurotrophin-3 (NT-3) (Hohn et al., 1990; Maisonpierre et al., 1990b), and neurotrophin-4 (NT-4) (Hallbrook et al., 1991). All these neurotrophic factors are expressed in high concentrations in the hippocampus as well as in other specific brain nuclei. BDNF is found throughout the adult brain in concentrations 50 times higher than NGF itself and may be trophic for a wide variety of neurons (Hofer et al., 1990; Maisonpierre et al., 1990a; Phillips et al., 1990; DiStefano et al., 1992; Ip et al., 1993). NT-3 expression is particularly high during embryogenesis and may influence development of the hippocampus (Ernfors et al., 1990b; Friedman et al., 1991; Collazo et al., 1992). The effects of these neurotrophins are mediated by a family of tyrosine receptor kinases (Trks) (Chao, 1992). NGF is the specific ligand for TrkA, while BDNF and NT-4 preferentially activate TrkB, and NT-3 activates TrkC and to a lesser extent TrkB.

The aim of this study was to determine if immobilization stress affects the expression of neurotrophic factors or their receptors in the hippocampal formation of the rat brain. Because chronic stress produces neuropathological changes in the hippocampus, we hypothesized that stress might decrease the expression of one or more of these neurotrophic factors or their receptors in the hippocampus. As TrkB and TrkC, but not TrkA, are present and functional in the adult hippocampus (Collazo et al., 1992; Ip et al., 1993; Marsh et al., 1993), we concentrated on their specific ligands, BDNF, NT-3 and NT-4, in the studies 
described here. We also addressed the relevance of glucocorticoids in mediating stress-induced changes in neurotrophin expression.

\section{Materials and Methods}

Stress, adrenalectomy, and corticosterone replacement. Male SpragueDawley rats $(280-320 \mathrm{gm})(n=6 /$ group $)$ from Taconic Farm (Germantown, NY) were immobilized for $2 \mathrm{hr} / \mathrm{d}$, once or on 7 consecutive days, by taping their limbs to a metal board as described previously (Kvetnansky and Mikulaj, 1970). Rats were decapitated immediately or $24 \mathrm{hr}$ after the last immobilization period. Control animals were handled daily and then sacrificed without further manipulation. All experiments were performed between 7 A.M. and 12 noon with lights off between 6 P.M. and 6 A.M. All animal procedures were approved by the NIMH and NINDS Animal Care and Use Committees.

To examine the effects of exogenous glucocorticoid administration, male Sprague-Dawley rats (200-240 gm) were injected subcutaneously once or on 7 consecutive days in the A.M. with corticosterone $(10 \mathrm{mg} /$ rat) (Sigma Chemicals Co., St. Louis, MO). Comparisons were made to control rats which were also sacrificed $2 \mathrm{hr}$ after injection of vehicle (sesame oil) once or on 7 consecutive days.

To examine the effects of removing endogenous glucocorticoids, male Sprague-Dawley rats $(230-280 \mathrm{gm})$ were bilaterally adrenalectomized (ADX) via a dorsal approach under methohexital anesthesia (50 $\mathrm{mg} / \mathrm{kg}$ ). Seven days after adrenalectomy, rats were immobilized once for $2 \mathrm{hr}$ and then immediately sacrificed. Unstressed ADX and sham rats were sacrificed $7 \mathrm{~d}$ after surgery without further manipulation.

In another experiment, animals were adrenalectomized and implanted with a $37.5 \mathrm{mg} 21 \mathrm{~d}$ release corticosterone pellet (Innovative Research of America, Toledo, $\mathrm{OH}$ ) at the time of adrenalectomy. Sham rats were anesthetized, received the same incision, and were implanted with a placebo pellet. Then each group of rats was subjected to immobilization stress $(2 \mathrm{hr} / \mathrm{d})$ or daily handling for 1 or 7 consecutive days. Rats were immediately sacrificed after the last immobilization.

All ADX animals (without corticosterone replacement) had undetectable plasma corticosterone levels $(<25 \mathrm{ng} / \mathrm{ml})$. Corticosterone was measured by radioimmunoassay using a kit from ICN Biomedicals Inc. (Cleveland, $\mathrm{OH}$ ). The intra-assay coefficient of variation was $<10 \%$.

Oligonucleotide in situ hybridization. Frozen brain sections $(15 \mu \mathrm{m})$ at the level of the dorsal hippocampus were cut on a cryostat, thaw mounted onto gelatin-coated slides and stored at $-70^{\circ} \mathrm{C}$ prior to in situ hybridization. The sections were fixed in $4 \%$ paraformaldehyde in phosphate-buffered saline (PBS) for $5 \mathrm{~min}$, rinsed in PBS, and then treated with $0.25 \%$ acetic anhydride in $0.1 \mathrm{M}$ triethanolamine $(\mathrm{pH} 8)$ for 10 min to reduce nonspecific hybridization of the probes. After dehydration in increasing concentrations of ethanol, the sections were delipidated in chloroform for $5 \mathrm{~min}$, rinsed in ethanol and air dried.

Oligonucleotides (48-mers) were synthesized on a Cyclone Plus DNA synthesizer (Milligen/Biosearch, Bedford, MA). The sequences were 5'CAGTTGGCCTTTTGATACCGGGACTTTCTCCAGGACTGTGACCGTCCC-3' complementary to bp 562-609 of rat BDNF (Maisonpierre et al., 1991); 5'-GCGTTTCCTCCGTGGTGATGTTCTATTGGTTACCACCGGGTTGCCCAC-3' complementary to bp 442-489 of rat NT-3 (Ernfors et al., 1990a); 5'-TTCTGAGAGCCAGTGCCTCCGATCCACGCCGCGACAGCCCCCTCCGCC-3' complementary to bp 535-582 of rat NT-4 (Ip et al., 1992); 5'-TACAACAAGGCATTGTTAGTTGTGGTGGGCAAACTGGAGTGTCTGCTG-3' complementary to bp 3548-3595 of the 3'-untranslated region of rat trkB $(+)$ containing tyrosine kinase activity (Middlemas et al., 1991); 5'-AGCTGCCTGACCCCTGCCTCTGCCTTGGGGTTCCCCAGTCACAGCTCA-3' complementary to bp 2036-2083 of the $3^{\prime}$-untranslated region of rat $\operatorname{trkB}(-)$ which is a truncated receptor without tyrosine kinase activity (Middlemas et al., 1991); and 5'-GAAGTGGCCGTTATGGTCTGGTTGGCTGTGCCCAGGGCATTCTTAGCAAT-3' specific for rat trkC as previously described (Merlio et al., 1992).

The oligonucleotide probes were labeled with ${ }^{35}$ S-dATP using terminal transferase (Boehringer Mannheim, Indianapolis, IN). For each slide containing two brain sections, $50 \mu \mathrm{l}$ of hybridization buffer containing $20 \mathrm{~mm}$ Tris- $\mathrm{HCl}$ (pH 7.4), $50 \%$ formamide, $300 \mathrm{~mm} \mathrm{NaCl}, 1$ mM EDTA (pH 8), $1 \times$ Denhardt's, $10 \mathrm{mg} / \mathrm{ml}$ salmon sperm DNA, $10 \%$ dextran sulfate, $100 \mathrm{~mm}$ dithiothreitol, and $1 * 10^{6} \mathrm{cpm}$ of the labeled oligonucleotide was added. Slides were incubated overnight at $37^{\circ} \mathrm{C}$ in a humidified chamber and then washed in $2 \times \mathrm{SSC} / 50 \%$ formamide (4
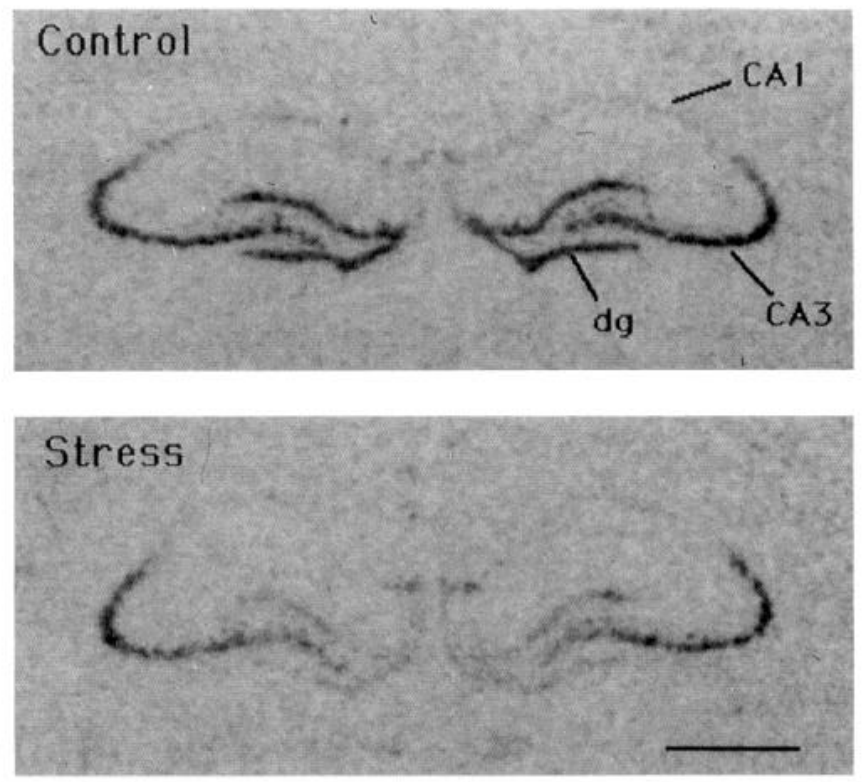

Figure 1. Autoradiographs of BDNF mRNA in the hippocampus. Note decrease in BDNF hybridization in the dentate gyrus $(d g)$ from the rat stressed on 7 consecutive days compared to the unstressed control rat. Scale bar, $1.5 \mathrm{~mm}$.

$\times 15 \mathrm{~min}$ each at $\left.40^{\circ}\right)$, and then $1 \times \mathrm{SSC}(2 \times 30 \mathrm{~min} ; 1 \times \mathrm{SSC}=$ $0.15 \mathrm{M} \mathrm{NaCl}, 0.015 \mathrm{~m}$ sodium citrate, $\mathrm{pH}$ 7.2.) Sections were apposed to Amersham b-max film for 7-21 d.

Autoradiograms were analyzed using a solid state camera, an Apple Macintosh system and image analysis software developed by Wayne Rasband at NIH. The brain area of interest was outlined using a density slice function which highlighted that area from neighboring tissue with less hybridization signal. We then averaged the optical density of the images from two to four sections from each animal and subtracted the background which was assumed to be equivalent to the amount of signal generated by the nonspecific sense probes. The optical density was corrected for nonlinearity of the film using a series of ${ }^{14} \mathrm{C}$ standards which had been matched to ${ }^{35} \mathrm{~S}$ brain paste standards and converted to $\mathrm{dpm} /$ $\mathrm{mg}$ wet tissue. Some sections were dipped in photographic emulsion (Kodak NTB-2) and developed after 4-6 weeks in D19 developer. They were counterstained with cresyl violet, dehydrated, and coverslipped in Permount.

Data are expressed as the mean of the percentage of the control mRNA levels \pm SD or SEM as indicated in the figure captions. Differences between groups were tested statistically by analysis of variance (ANOVA) followed by the post hoc Tukey-Kramer comparison for multiple groups using SUPERANOVA software.

\section{Results}

The effects of acute and repeated immobilization stress on BDNF mRNA expression in the hippocampus were assessed by densitometric analysis of autoradiographs from in situ hybridization with a ${ }^{35} \mathrm{~S}$-labeled oligonucleotide probe. In unstressed rats, BDNF mRNA was abundantly present in the granular layer of the dentate gyrus as well as the CA2, CA3, and CA4 layers of the hippocampus with somewhat less expression in the CA1 region similar to previous observations (Ernfors et al., 1990b; Hofer et al., 1990; Phillips et al., 1990). However, in rats subjected to immobilization stress, we found that BDNF mRNA was markedly decreased throughout the hippocampus and especially in the dentate gyrus (Figs. 1-3). In the dentate gyrus, stress reduced BDNF mRNA to about $25 \%$ of basal levels (Fig. 3). This decrease in BDNF occurred after a single $2 \mathrm{hr}$ immobilization period, and the magnitude of the decrease was no greater 

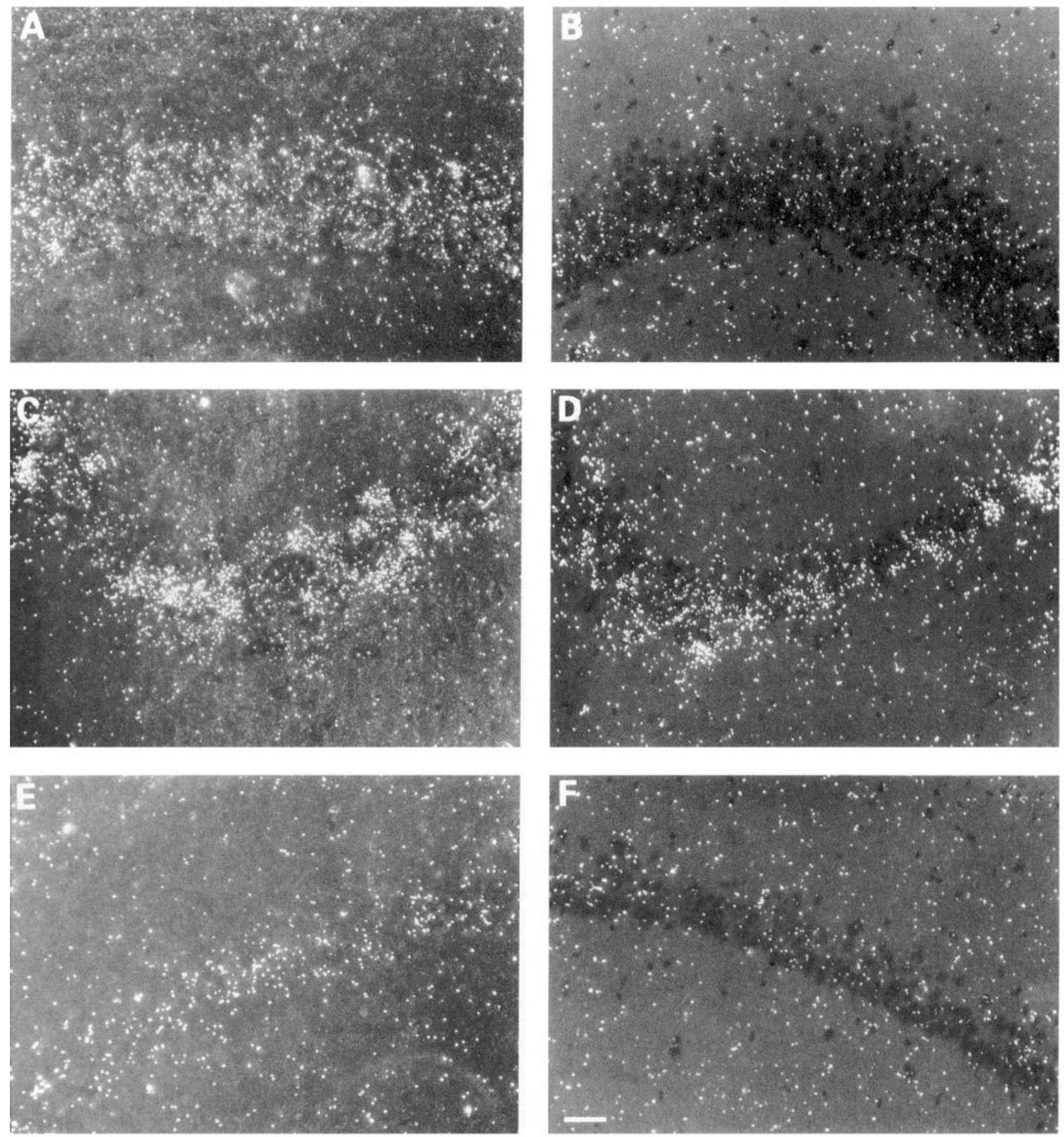

Figure 2. Dark-field photomicrographs of BDNF in situ hybridization in an unstressed $(A, C, E)$ and $7 \times$ stressed rat $(B, D, F)$. Dentate gyrus $(A, B), \mathrm{CA} 3(C, D), \mathrm{CA} 1(E, F)$. White silver grains indicate hybridization of radiolabeled BDNF probe to BDNF mRNA. Cells were counterstained with cresyl violet. Scale bar, $40 \mu \mathrm{m}$.

following repeated acute immobilization stress for 7 consecutive days (Fig. 3).

The ability of immobilization stress to decrease BDNF mRNA in the hippocampus was less robust than in the dentate gyrus but still significant as shown in Figures 1-3. The dark-field photomicrographs in Figure 2 demonstrate that some hippocampal neurons normally express much more BDNF than others, which is particularly evident in CA3 pyramidal neurons (Fig. 2C) and consistent with previous observations (Hofer et al., 1990). This heterogeneous level of expression was also evident following immobilization (Fig. 2D), but overall, the average level of BDNF mRNA was dramatically reduced.

The effect of stress on BDNF was rapid, occurring in as little as $1 \mathrm{hr}$ after the beginning of stress (results not shown), and somewhat transient, as BDNF levels at $24 \mathrm{hr}$ after the end of the stress period were intermediate between the maximal de- 


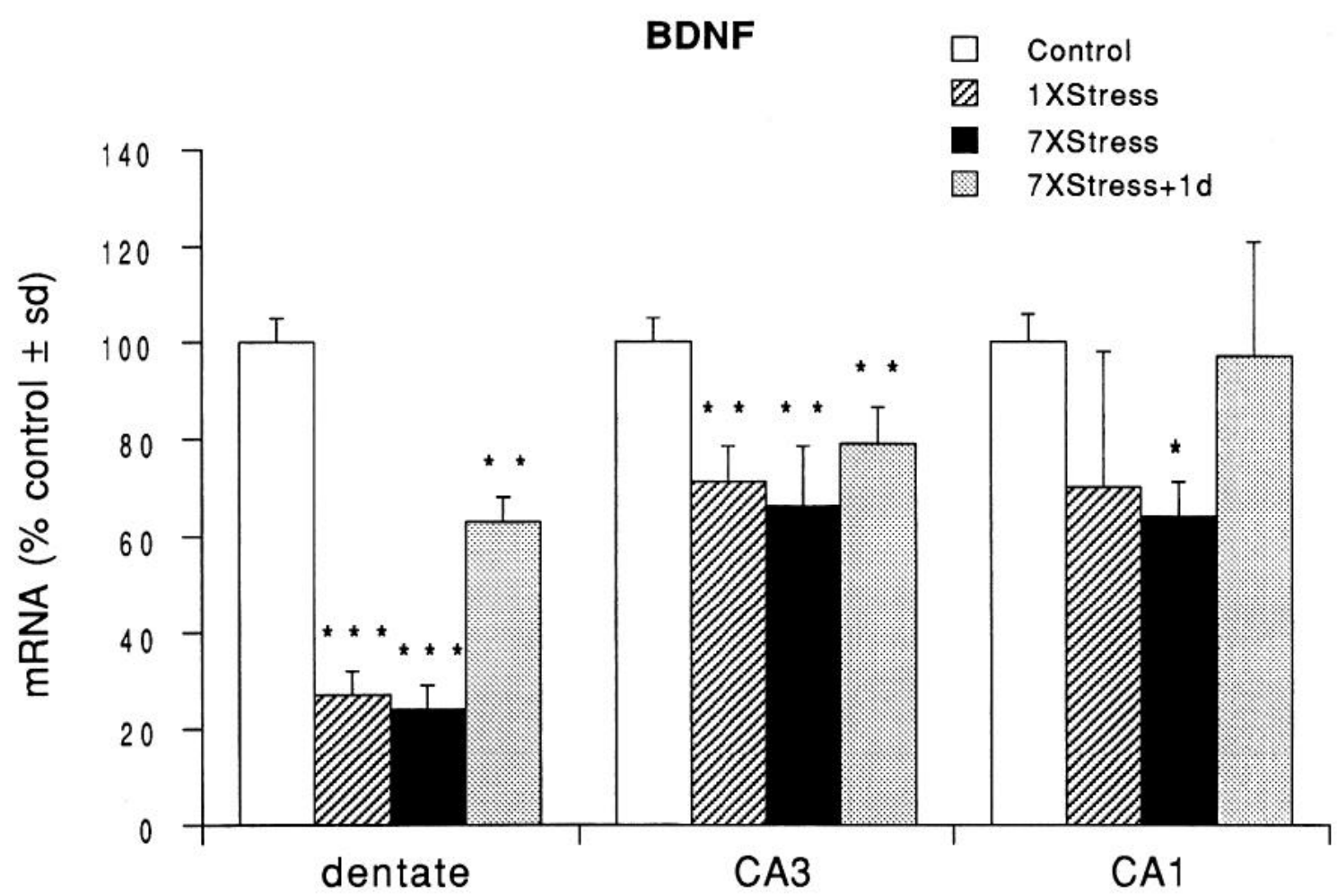

Figure 3. Effects of single or repeated stress on BDNF mRNA in the dentate gyrus, CA3 and CA1 hippocampal layers. Data are expressed as the mean of the percentage of the unstressed control group \pm SD. Groups ( $n=6$ rats/group) were significantly different from unstressed control group at $*, p<0.05 ; * *, p<0.01 ;$ or $* * *, p<0.001$.

crease and control values (Fig. 3). BDNF mRNA levels did not change significantly in the cerebral cortex in response to stress (results not shown), but BDNF was decreased by stress in other areas of the limbic system (Smith et al., unpublished observations).

Neurotrophin-3 mRNA, in contrast to BDNF, was increased in the dentate gyrus as well as the CA2 and medial CA1 pyra-
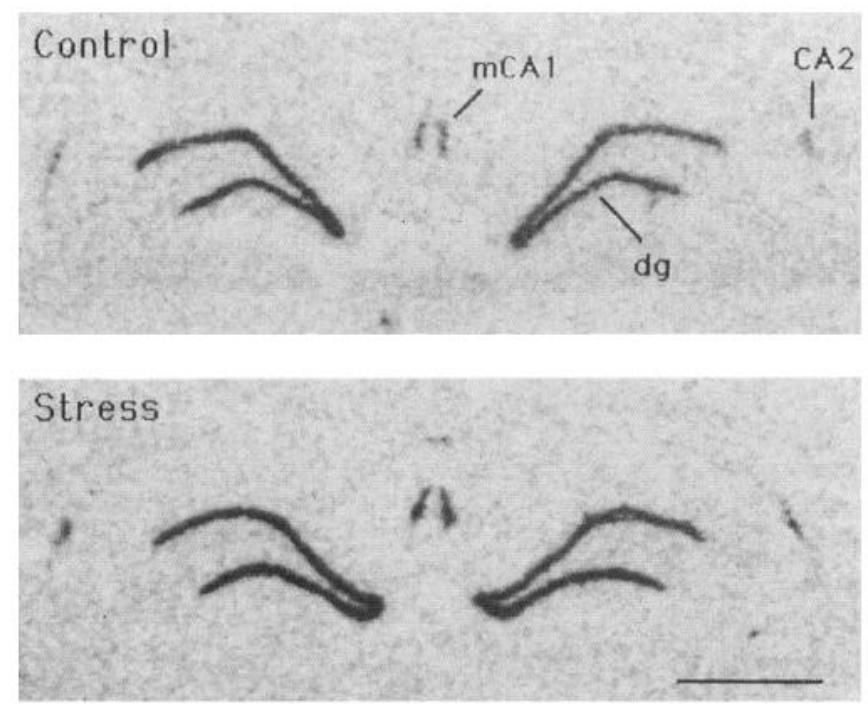

Figure 4. Autoradiographs of NT-3 mRNA in the hippocampus from unstressed control and a stressed rat. Note increases in NT-3 hybridization in the dentate gyrus $(d g), \mathrm{CA} 2$ and the medial CA1 hippocampal regions from the rat stressed on 7 consecutive days. Scale bar, $1.5 \mathrm{~mm}$. midal neurons in response to repeated immobilization stress for 7 d (Figs. 4-6). A single acute stress did not consistently elevate NT-3 mRNA levels (Fig. 6). NT-3 mRNA levels did not change in the tinea tecta or cerebellum in response to immobilization stress (results not shown), but NT-3 expression was increased in the locus ceruleus by stress (Smith et al., unpublished observations).

Immobilization stress had no effect on NT-4 expression in the hippocampus. Likewise stress had no effect on mRNA levels of tyrosine kinase receptors including $\operatorname{trkB}(+)$ (containing tyrosine kinase activity), $\operatorname{trkb}(-)$ (without tyrosine kinase activity), and trkC (results not shown).

We next asked the question whether administration of $10 \mathrm{mg}$ corticosterone would mimic the effects of stress on BDNF and NT-3 expression. We chose this dose of corticosterone because it has been used by other groups to produce hippocampal damage (Wooley et al., 1990). Corticosterone injections raised plasma corticosterone levels to $822 \pm 92$ and $952 \pm 122 \mathrm{ng} / \mathrm{ml}$ after one or seven injections respectively whereas the corresponding vehicle-injected controls were $52 \pm 15$ and $83 \pm 23$ $\mathrm{ng} / \mathrm{ml} \pm$ SEM. (These corticosterone levels produced $2 \mathrm{hr}$ after $10 \mathrm{mg}$ corticosterone injection were greater than or equal to those measured in immobilized animals which ranged from 350$675 \mathrm{ng} / \mathrm{ml}$.) Administration of corticosterone reduced BDNF mRNA in the dentate gyrus to levels which were $65-75 \%$ of those seen in the vehicle-injected controls (Fig. 7). In this experiment, the effects of corticosterone on BDNF mRNA were not readily apparent in the CA3 and CA1 pyramidal layers of the hippocampus (Fig. 7). In a similar manner to that seen with stress, a single injection of corticosterone did not significantly affect NT-3, but 7 daily injections markedly increased NT-3 

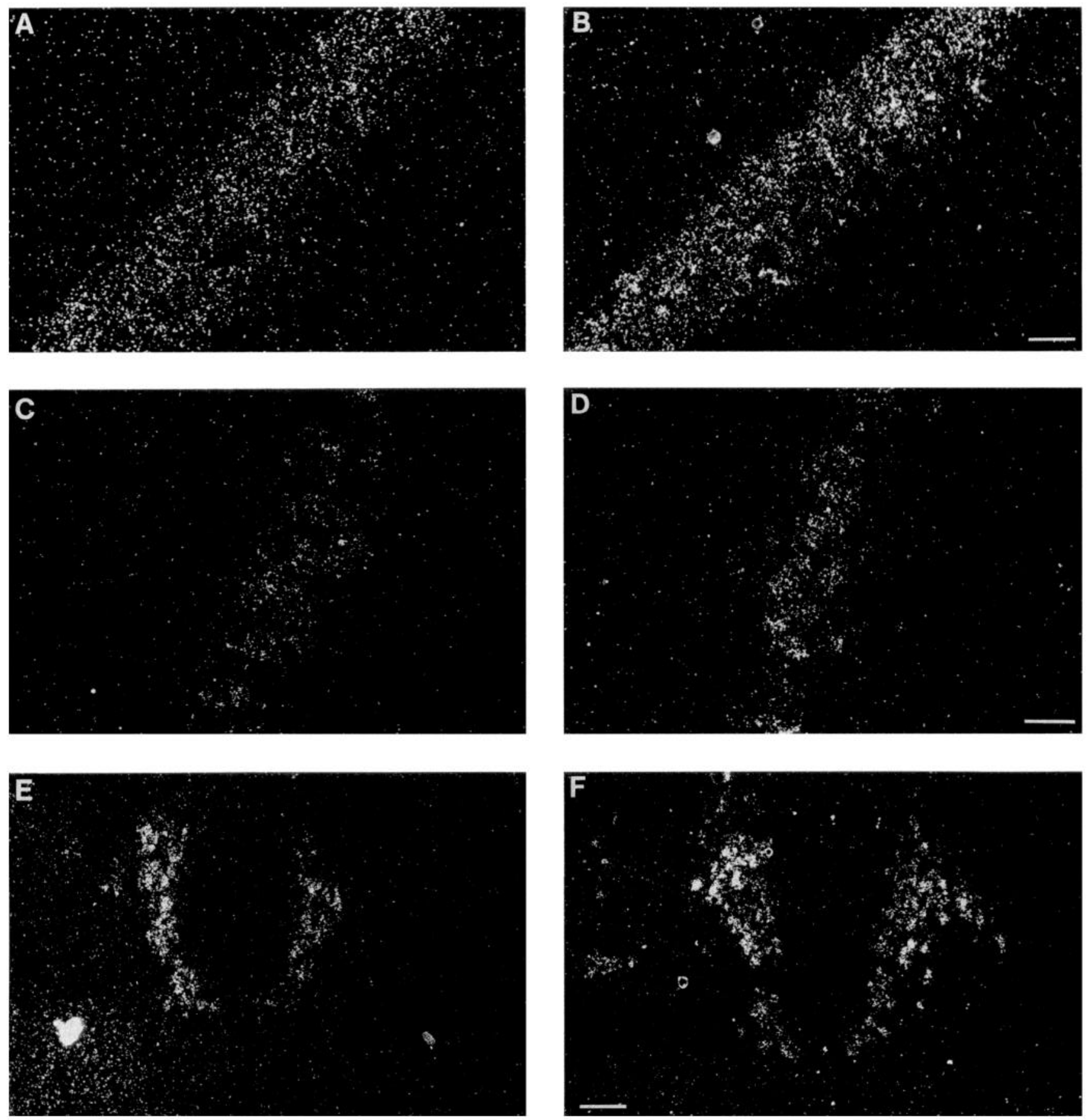

Figure 5. Dark-field photomicrographs of NT-3 in unstressed $(A, C, E)$ and $7 \times$ stressed rat $(B, D, F)$. Dentate gyrus $(A, B)$, CA2 $(C, D)$, medial $\mathrm{CA} 1(E, F)$. Scale bars: $B$ and $D, 20 \mu \mathrm{m} ; F, 40 \mu \mathrm{m}$.

mRNA levels in the dentate gyrus as well as the hippocampus (Fig. 7).

To determine if the stress-induced changes in BDNF and NT-3 could occur in the absence of glucocorticoids, we examined the effects of acute immobilization stress on BDNF and NT-3 mRNA expression in adrenalectomized rats. The stressmediated decrease in BDNF still occurred in the dentate gyrus but was largely prevented in the hippocampus of ADX rats (Fig. 8). Adrenalectomy did not affect basal levels of BDNF mRNA. In contrast, adrenalectomy significantly decreased basal levels of NT-3 mRNA in the dentate gyrus and especially in CA2 and CA1 pyramidal neurons (Fig. 8). A single immobilization did not increase NT-3 mRNA levels in either the sham or ADX rats.

To examine further whether the effects of repeated stress on BDNF and NT-3 expression were dependent on glucocorticoids, we stressed rats whose endogenous glucocorticoids had been removed by adrenalectomy and replaced with a $37.5 \mathrm{mg}$ corticosterone pellet. This pellet maintained plasma corticosterone levels at levels similar to those in unstressed sham-operated rats. See Table 1. However, the pellet did increase glucocorticoid 


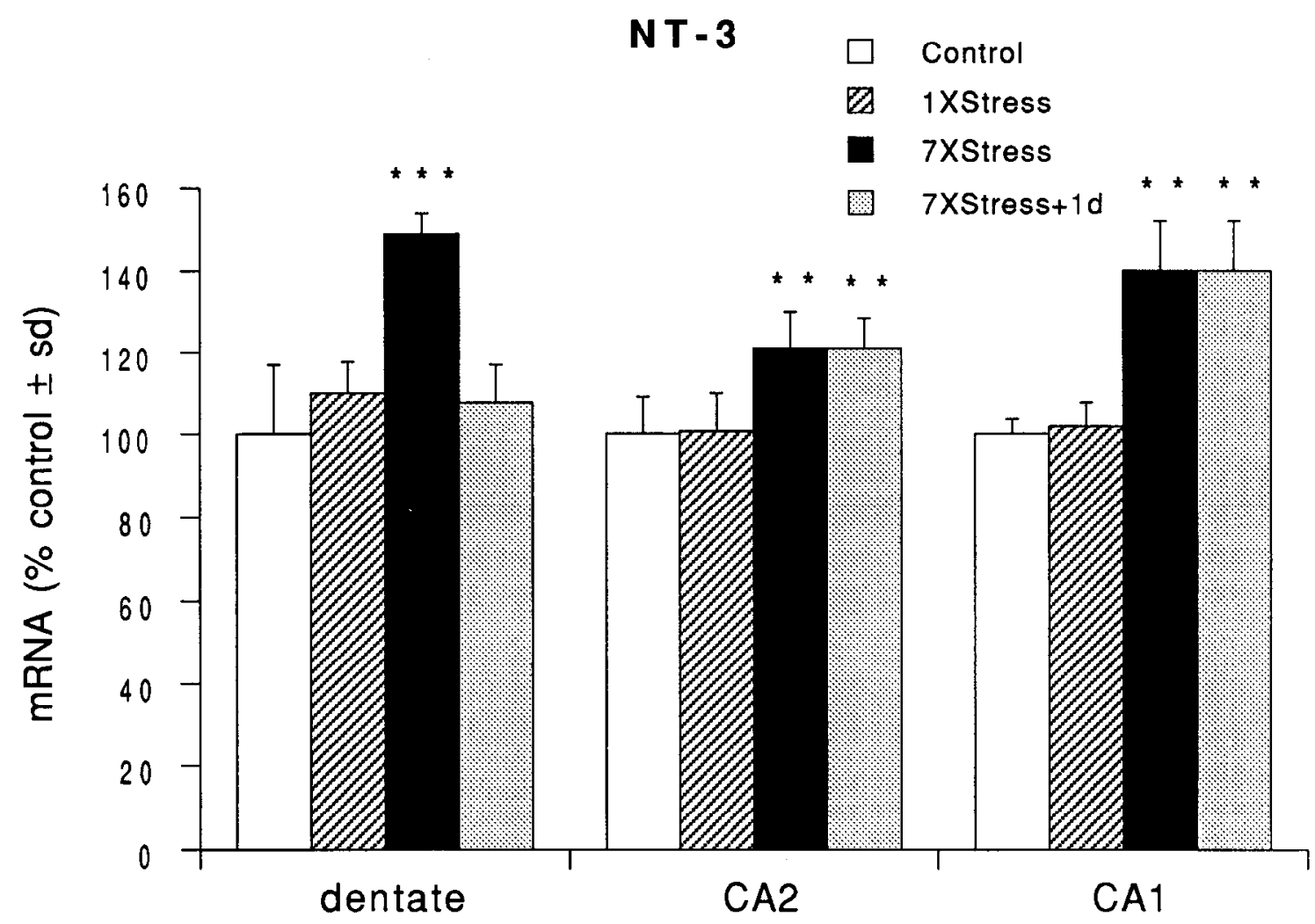

Figure 6. Effects of single or repeated stress on NT-3 mRNA in the dentate gyrus, CA2 and CA1 hippocampal layers. Data from same experiment as Figure 3. Groups were different from unstressed controls at ${ }^{* *}, p<0.01$; or $* * *, p<0.001$.

feedback to some extent as thymus weights were reduced in the ADX/corticosterone-replaced animals. This increased negative feedback was reflected in a decrease in BDNF mRNA levels in the dentate gyrus and hippocampus in the unstressed ADX/Cortreplaced rats (Table 1 ). Nevertheless, in the absence of any further increase in corticosterone feedback, immobilization stress reduced BDNF expression to levels that were significantly lower than those measured in the unstressed ADX/Cort-replaced rats and similar to the values in the stressed sham groups. Thus, fixing corticosterone levels near baseline did not prevent the stress-induced reduction in BDNF. In contrast, NT-3 mRNA expression was significantly increased only by repeated stress and only in animals which were adrenally intact (Table 1).

\section{Discussion}

We found that a form of stress, immobilization, was capable of altering the expression of certain neurotrophic factors, BDNF and NT-3, in the rat hippocampus. The effects of immobilization stress on neurotrophic factor expression were specific in that we observed no changes in neurotrophin- 4 , trkB, or trkC mRNA levels. Although we did not examine NGF expression, it is possible that stress may affect this growth factor as well. Indeed an increase in NGF mRNA in the hypothalamus has becn reported following social conflict in mice (Spillantini et al., 1989), and a decrease in NGF binding was observed after cold stress (Taglialatela et al., 1990). Thus, other stress paradigms may reveal additional changes in neurotrophic factors and their receptors.

The stress-induced changes in BDNF and NT-3 expression are largely opposite to those produced by seizures and ischemia. For instance, BDNF mRNA is increased throughout the brain up to 40 fold whereas NT-3 is decreased by $50 \%$ in the dentate gyrus by various seizure paradigms (Ernfors et al., 1991; Isackson et al., 1991; Gall and Lauterborn, 1992; Rocamora et al., 1992). Likewise, ischemia induces a transient increase in BDNF mRNA in the dentate gyrus and a decrease in NT-3 mRNA in the dentate gyrus, CA1 and CA2 layers (Lindvall et al., 1992; Takeda et al., 1992; Takeda et al., 1993). The direction of these observed changes in BDNF and NT-3 mRNA levels induced by seizures or ischemia is consistent with the notion that glutamate, which is released during seizures and ischemia, positively regulates BDNF expression (Zafra et al., 1991, 1992) and negatively regulates NT-3 (Lindvall et al., 1992). The fact that stress induces effects opposite to those caused by seizures and ischemia might imply that the underlying mechanisms driving growth factor expression are opposite too. Yet, restraint stress, like seizures and ischemia, has been reported to increase glutamate turnover (Gilad et al., 1990; Moghaddam, 1993). Perhaps additional neurotransmitters, such as norepinephrine, 5-HT, or GABA, may be important in the regulation of neurotrophic factor expression during stress.

Evidence for a stimulatory effect of glucocorticoids on NT-3 expression is provided by the fact that NT-3 mRNA levels increased in response to corticosterone administration and decreased following adrenalectomy similar to previous reports (Barbany and Persson, 1992; Denton et al., 1992). Moreover, repeated stress which increased NT-3 in intact rats failed to do so in adrenalectomized rats whose corticosterone levels were kept near baseline (Table 1). Interestingly, repeated administration of large doses of corticosterone (or time points longer than $2 \mathrm{hr}$ after a single injection) seemed to be required for induction of NT-3. Thus, the stress-induced increases in NT-3 expression 

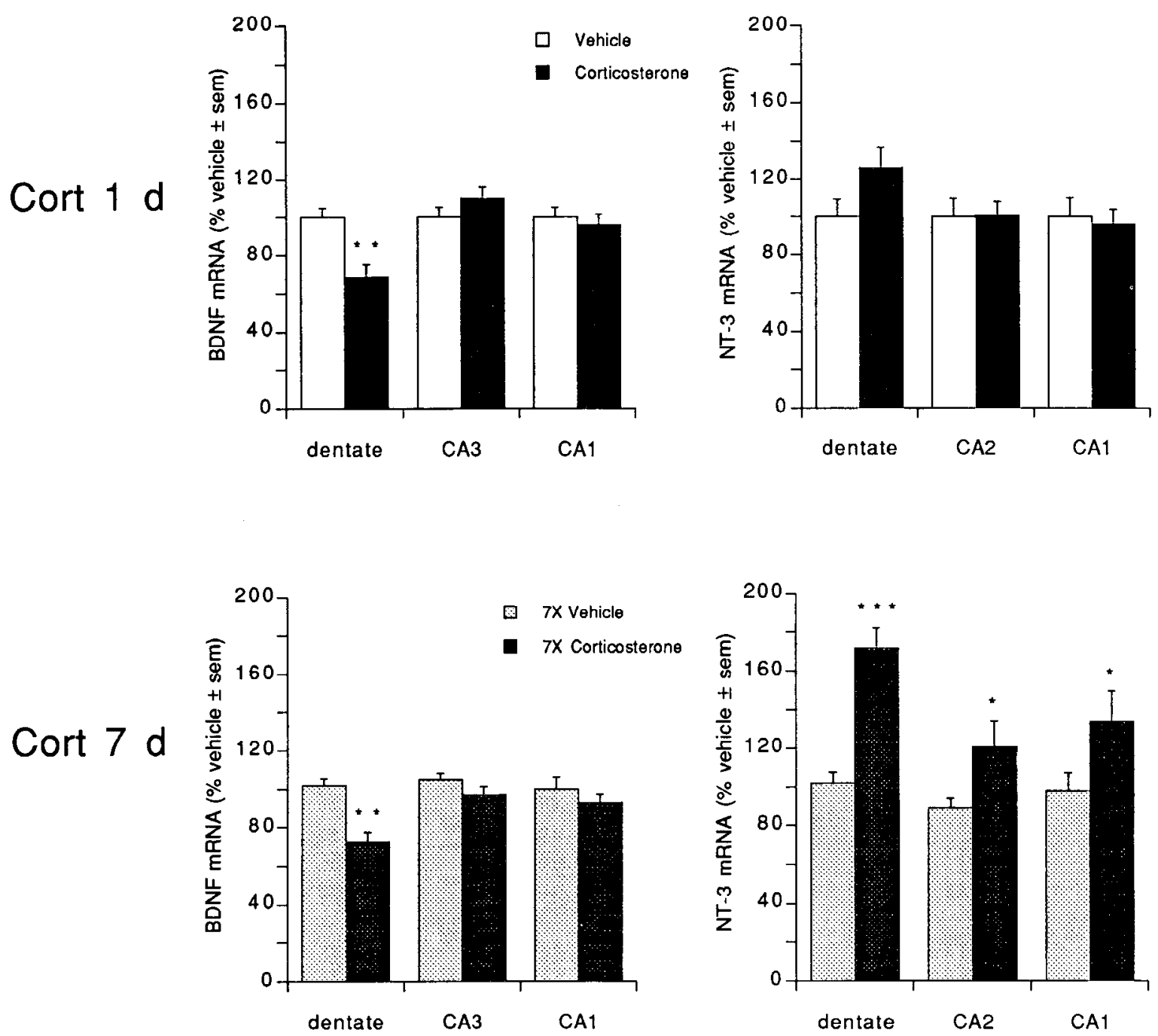

Figure 7. Effects of corticosterone administration (10 mg/rat) on BDNF and NT-3 mRNA levels in the dentate gyrus. Rats $(n=7-12 /$ group) were administered corticosterone for 1 or $7 \mathrm{~d}$ and compared to their corresponding control groups injected with vehicle for 1 or $7 \mathrm{~d}$. Data are expressed as the mean \pm SEM of the percentage of the $1 \mathrm{~d}$ vehicle-injected control group. However, statistical differences were evaluated by comparing the corticosterone-treated group with its matched vehicle-injected control group (either 1 or $7 \mathrm{~d}$ ). Groups were significantly different from the $1 \times$ or $7 \times$ vehicle-injected control group at ${ }^{*}, p<0.05 ; * *, p<0.01$; or ${ }^{* * *}, p<0.001$ by Student's $t$ test with Bonferroni correction.

may be explained by high levels of corticosterone secreted during repeated stress.

The role of corticosterone in mediating the stress-induced decrease in BDNF is less clear. While corticosterone generally appeared to decrease BDNF, the effect was small, and either confined to the dentate gyrus or required more than $2 \mathrm{hr}$ exposure (Fig. 7, Table 1). Also stress was able to decrease BDNF in the absence of glucocorticoids, at least in the dentate gyrus (Fig. 8). This suggests that corticosterone feedback is not the only part of the stress response contributing to the observed decrease in BDNF mRNA. However, because the most robust and consistent decreases in BDNF occurred in stressed animals which were adrenally intact, it is likely that basal levels of glucocorticoids are necessary for maximal inhibition of BDNF mRNA by stress (Fig. 8, Table 1), just as glucocorticoids are required for maximal stimulation of BDNF by kainic acid (Barbany and Persson, 1993).
The fact that stress or corticosterone not only produce deleterious effects on C.A3 dendrites (Wooley et al., 1990; Watanabe et al., 1992) and cell viability (Sapolsky, 1992), but also decrease BDNF expression suggests that reduced BDNF availability might contribute to the pathological effects produced by stress or high levels of corticosterone. In the mature CNS the consequence of withdrawing neurotrophic factor support does not necessarily lead to neuronal death (Sofroniew et al., 1993). Therefore, a partial reduction in BDNF may not be sufficient by itself to damage or destroy hippocampal neurons during aging or chronic stress, but it could make neurons more vulnerable to the exacerbation of excitotoxic injury by stress or glucocorticoids. In this regard it is of interest that BDNF protects CNS neurons in culture from glutamate neurotoxicity or glucose deprivation-induced injury (Cheng and Mattson, 1994).

Neurotrophic factors have dramatic effects on the morphology of mature neurons. For instance, NGF increases dendritic length 

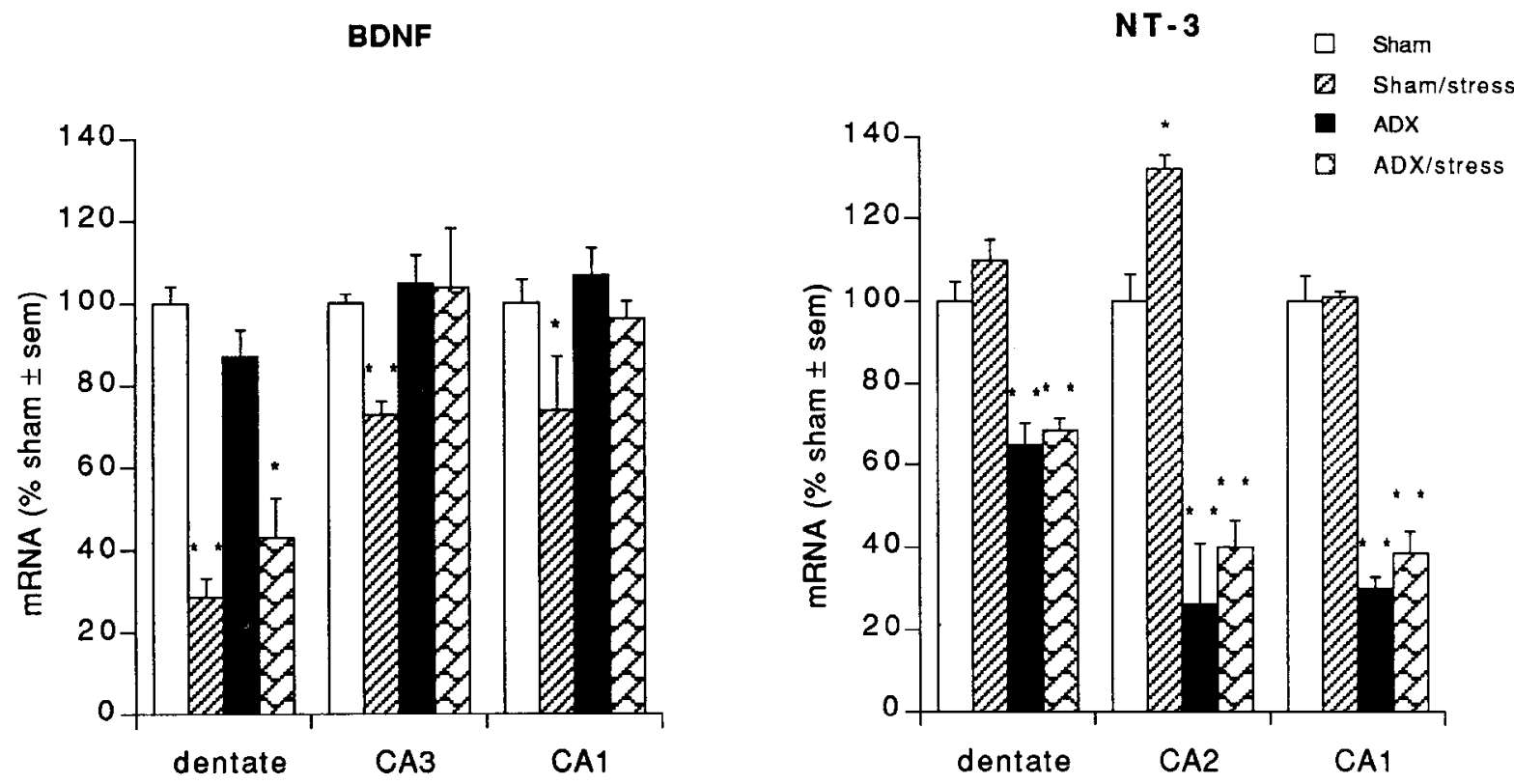

Figure 8. Effects of a single $2 \mathrm{hr}$ immobilization stress on BDNF and NT-3 mRNA levels in the dentate gyrus in sham-operated and adrenalectomized $(A D X)$ rats. Data are given as the mean \pm SEM expressed as the percentage of the unstressed sham group. Groups ( $n=4-12$ rats/group) were significantly different from unstressed sham group at ${ }^{*}, p<0.05$; or ${ }^{* *}, p<0.01$.

and branching while NGF antiserum reduces these two dendritic parameters in the adult sympathetic ganglion (Ruit et al., 1990). By analogy then, withdrawal of BDNF could contribute to the reduction in $\mathrm{CA} 3$ apical dendrites observed during chronic stress (Watanabe et al., 1992). BDNF support of CA3 neurons could be derived from target cells in the CAl pyramidal layer where BDNF is normally expressed in low levels and further reduced by immobilization stress.

Neurotrophic factors might also affect axonal sprouting. It has been suggested that BDNF and noncatalytic trkB receptors are important in mediating axonal sprouting that occurs in the molecular layer of the dentate gyrus following combined lesions of the fimbria-fornix and perforant path (Beck et al., 1993). Moreover, the very large increase in BDNF mRNA induced by amygdala kindling (Isackson et al., 1991) is associated with axonal sprouting of the dentate mossy fibers (Sutula et al., 1988). If the reverse were true, that is, a reduction in BDNF causes retraction of axons, then stress might lead to a retraction of mossy fiber axons from the apical dendrites of CA3 hippocampal neurons with subsequent changes in dendrite morphology (Nitsch and Frotscher, 1991).

Changes in neurotrophic factor expression could have physiological consequences. Inescapable stress has been shown to inhibit long-term potentiation (Shors et al., 1989), a model of learning and memory. As neurotrophic factors have been implicated in LTP (O'Dell et al., 1991; Dragunow et al., 1993), it is conceivable that stress might have deleterious effects on cognition via its negative regulation of neurotrophic factors such as BDNF (Falkenburg et al., 1992). BDNF expression is decreased in the hippocampus of patients with Alzheimer's disease and may contribute to the progressive loss of neurons and cognitive function associated with this illness (Phillips et al., 1991).

The increase in neurotrophin-3 expression following stress was unexpected as we had predicted that the neuropathological effects of chronic stress would be associated with a reduction, not an increase, in a growth factor. What the functional consequences of the observed increase in NT-3 mRNA might be are presently unknown, but one hypothesis would be that it repre-

Table 1. Effects of stress on BDNF and NT-3 in adrenalectomized/corticosterone-replaced rats

\begin{tabular}{|c|c|c|c|c|c|c|c|c|c|}
\hline \multirow[b]{2}{*}{ Treatment } & \multirow[b]{2}{*}{$n$} & \multirow{2}{*}{$\begin{array}{l}\text { Cortico- } \\
\text { sterone } \\
(\mathrm{ng} / \mathrm{ml})\end{array}$} & \multirow{2}{*}{$\begin{array}{l}\text { Thymus } \\
\text { (mg/loo } \\
\text { gm bw) }\end{array}$} & \multicolumn{3}{|c|}{$\begin{array}{l}\text { BDNF mRNA } \\
\text { (\% sham) }\end{array}$} & \multicolumn{3}{|l|}{$\begin{array}{l}\text { NT-3 mRNA } \\
\text { (\% sham) }\end{array}$} \\
\hline & & & & Dentate & CA3 & CA1 & Dentate & CA2 & CA1 \\
\hline Sham no stress & 7 & $70 \pm 16$ & $158 \pm 6$ & $100 \pm 15$ & $100 \pm 10$ & $100 \pm 11$ & $100 \pm 9$ & $100 \pm 11$ & $100 \pm 6$ \\
\hline Sham $1 \times$ stress & 6 & $431 \pm 23^{* *}$ & $113 \pm 14$ & $31 \pm 5^{* *}$ & $62 \pm 11^{*}$ & $62 \pm 3 * *$ & $112 \pm 10$ & $91 \pm 18$ & $106 \pm 5$ \\
\hline Sham $7 \times$ stress & 7 & $442 \pm 18^{* *}$ & $128 \pm 10$ & $19 \pm 4^{* *}$ & $57 \pm 5^{* *}$ & $59 \pm 5^{* *}$ & $152 \pm 10^{* *}$ & $144 \pm 11^{*}$ & $132 \pm 11^{*}$ \\
\hline $\mathrm{ADX} /$ Cort no stress & 11 & $67 \pm 5$ & $87 \pm 8^{*}$ & $62 \pm 6^{*}$ & $73 \pm 5^{*}$ & $76 \pm 4^{*}$ & $92 \pm 3$ & $103 \pm 4$ & $103 \pm 6$ \\
\hline ADX/Cort $1 \times$ stress & 8 & $108 \pm 6$ & $92 \pm 10^{*}$ & $36 \pm 3^{* * \#}$ & $60 \pm 6^{* *}$ & $61 \pm 4 * * \#$ & $96 \pm 11$ & $111 \pm 4$ & $115 \pm 6$ \\
\hline ADX/Cort $7 \times$ stress & 10 & $92 \pm 8$ & $97 \pm 9^{*}$ & $30 \pm 3^{* * \#}$ & $51 \pm 4^{* *}$ & $47 \pm 2 * * \# \#$ & $108 \pm 9$ & $124 \pm 12$ & $112 \pm 6$ \\
\hline
\end{tabular}

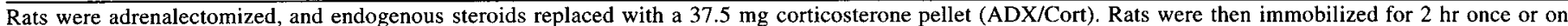

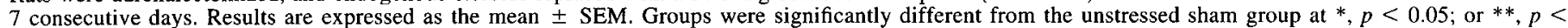
0.01 ; or different from the unstressed ADX/Cort group at $\#, p<0.05$; or \#\#, $p<0.01$ by ANOVA and Tukey-Kramer post hoc test. 
sents a compensatory response aimed at preventing or repairing stress-induced damage. For instance, NT-3 increases the number of hippocampal neurons producing the calcium-binding protein, calbindin- $\mathrm{D}_{28 \mathrm{k}}$ (Collazo et al., 1992), which is intriguing in light of other studies indicating that the absence of calbindin- $\mathrm{D}_{28 \mathrm{k}}$ is associated with vulnerability to damage in the hippocampus (Sloviter, 1989). The increase in NT-3 mRNA observed after repeated stress might also be important for behavioral adaptation to future stressors.

Neurotrophin-3 may play a role in the development and maintenance of the dentate gyrus. NT-3 mRNA levels in the rat brain reach their peak during the first 3 weeks of life when most of the dentate granule neurons are dividing (Maisonpierre et al., 1990a). As some granule neurons continue to divide even in adulthood (Gould et al., 1992), it is possible that NT-3 may continue to affect this process. It is also intriguing that granule neurons, which are spared by stress, respond by increasing their expression of NT-3 mRNA. Furthermore, adrenalectomy which negatively affects granule cell survival (Sloviter et al., 1989), decreases NT-3 mRNA in the dentate granule neurons (Denton et al., 1992). It is conceivable that NT-3 regulates granule neurons via an autocrine mechanism of action based on the fact that granule neurons express both NT-3 and trkC, and granule neurons respond to NT-3 by producing c-Fos (Collazo et al., 1992). It will be important then to determine if NT-3 is neuroprotective for dentate granule neurons or other neurons which are spared by stress.

In conclusion this study demonstrates that changes in the expression of neurotrophic factors are part of the brain's response to stress. Whether changes in neurotrophic factor availability actually contribute to the damage in the hippocampus caused by stress or are of adaptive value for facing future stressors remains to be explored.

\section{References}

Barbany G, Persson H (1992) Regulation of neurotrophin mRNA expression in the rat brain by glucocorticoids. Eur J Neurosci 4:396403.

Barbany G, Persson H (1993) Adrenalectomy attenuates kainic acidelicited increases of messenger RNAs for neurotrophins and their receptors in the rat brain. Neuroscience 54:909-922.

Beck KD, Lamballe F, Klein R, Barbacid M, Schauwecker PE, McNeill TH, Finch CE, Hefti F, Day JR (1993) Induction of noncatalytic trkB neurotrophin receptors during axonal sprouting in the adult hippocampus. J Neurosci 13:4001-4014.

Chao MV (1992) Neurotrophin receptors: a window into neuronal differentiation. Neuron 9:583 593.

Cheng B, Mattson MP (1994) NT-3 and BDNF protect CNS neurons against metabolic/excitotoxic insults. Brain Res 640:56-67.

Collazo D, Takahashi H, McKay RDG (1992) Cellular targets and trophic functions of neurotrophin-3 in the developing rat hippocampus. Neuron 9:643-656.

Denton TL, Dugich-Djordjevic MN, Nichols NR, Davenport CJ, Finch CE, Hefti F (1992) Changes in the expression of the neurotrophins BDNF and NT3 may mediate the dependence of hippocampal neurons on glucocorticoid levels. Soc Neurosci Abstr 18:A387.5.

DiStefano PS, Friedman B, Radziejewski C, Alexander C, Boland P, Schick CM, Lindsay RM, Wiegand SJ (1992) The neurotrophins BDNF, NT-3, and NGF display distinct patterns of retrograde axonal transport in peripheral and central neurons. Neuron 8:983-993.

Dragunow M, Beilharz E, Mason B, Lawlor P, Abraham W, Gluckman $P$ (1993) Brain-derived neurotrophic factor expression after longterm potentiation. Neurosci Lett 160:232-236.

Ernfors P, Ibanez CF, Ebendal T, Olson L, Persson H (1990a) Molecular cloning and neurotrophic activities of a protein with structural similarities to nerve growth factor: developmental and topographical expression in the brain. Proc Natl Acad Sci USA 87:5454-5458.

Ernfors P, Wetmore C, Olson L, Persson H (1990b) Identification of cells in rat brain and peripheral tissues expressing mRNA for members of the nerve growth factor family. Neuron 5:511-526.

Ernfors P, Bengzon J, Kokaia Z, Persson H, Lindvall O (1991) Increased levels of messenger RNAs for neurotrophic factors in the brain during kindling epileptogenesis. Neuron 7:165-176.

Falkenburg T, Mohammed AK, Henriksson B, Persson H, Winblad B, Lindefors $N$ (1992) Increased expression of brain-derived neurotrophic factor mRNA in rat hippocampus is associated with improved spatial memory and enriched environment. Neurosci Lett 138:153156.

Friedman WJ, Ernfors P, Persson H (1991) Transient and persistent expression of NT-3/HDNF mRNA in the rat brain during postnatal development. J Neurosci 11:1577-1584.

Gall C, Lauterborn J (1992) The dentate gyrus: a model system for studies of neurotrophin regulation. Epilepsy Res [Suppl] 7:171-185.

Gilad G, Gilad V, Wyatt R, Tizabi Y (1990) Region-selective stressinduced increase of glutamate uptake and release in rat forebrain. Brain Res 525:335-338.

Gould E, Cameron HA, Daniels DC, Woolley CS, McEwen BS (1992) Adrenal hormones suppress cell division in the adult rat dentate gyrus. J Neurosei 12:3642-3650.

Hallbrook F, Ibanez CF, Persson H (1991) Evolutionary studies of the nerve growth factor family reveal a novel member abundantly expressed in Xenopus ovary. Neuron 6:845-858.

Hofer M, Pagliusi SR, Hohn A, Leibrock J, Barde Y-A (1990) Regional distribution of brain-derived neurotrophic factor mRNA in the adult mouse brain. EMBO J 9:2459-2464.

Hohn A, Leibrock J, Bailey K, Barde Y-A (1990) Identification and characterization of a novel member of the nerve growth factor/brainderived neurotrophic factor family. Nature 344:339-341.

Ip NY, Ibanez CF, Nye SH, McClain J, Jones PF, Gies DR, Belluscio L, Le Beau MM, Espinoza R, Squinto SP, Persson H, Yancopoulos GD (1992) Mammalian neurotrophin-4: structure, chromosomal localization, tissue distribution, and receptor specificity. Proc Natl Acad Sci USA 89:3060-3064.

Ip NY, Li Y, Yancopoulos GD, Lindsay RM (1993) Cultured hippocampal neurons show response to BDNF, NT-3, and NT-4, but not NGF. J Neurosci 13:3394-3405.

Isackson PJ, Huntsman MM, Murray KD, Gall CM (1991) BDNF mRNA expression is increased in adult rat forebrain after limbic seizures: temporal patterns of induction distinct from NGF. Neuron 6:937-948.

Johnson EO, Kamilaris TC, Chrousos GP, Gold PW (1992) Mechanisms of stress: a dynamic overview of hormonal and behavioral homeostasis. Neurosci Biobehav Rev 16:115-130.

Kvetnansky R, Mikulaj L (1970) Adrenal and urinary catecholamines in rats during adaptation to repeated immobilization stress. Endocrinology 87:738-743.

Landfield P (1987) Modulation of brain aging correlates by long-term alterations of adrenal steroids and neurally-active peptides. Prog Brain Res 72:279-300.

Leibrock J, Lottspeich F, Hohn A, Hofer M, Hengerer B, Masiakowski P, Thoenen H, Barde Y-A (1989) Molecular cloning and expression of brain-derived neurotrophic factor. Nature 341:149-152

Lindvall O, Ernfors P, Bengzon J, Kokaia Z, Smith M-J, Siesjo BK, Persson H (1992) Differential regulation of mRNAs for nerve growth factor, brain-derived neurotrophic factor, and neurotrophin 3 in the adult rat brain following cerebral ischemia and hypoglycemic coma. Proc Natl Acad Sci USA 89:648-652.

Maisonpierre PC, Belluscio L, Friedman B, Alderson RF, Wiegand SJ, Furth ME, Lindsay RM, Yancopoulos GD (1990a) NT-3, BDNF, and NGF in the developing rat nervous system: parallel as well as reciprocal patterns of expression. Neuron 5:501-509.

Maisonpierre PC, Belluscio L, Squinto S, Ip NY, Furth ME, Lindsay RM, Yancopoulos GD (1990b) Neurotrophin-3: a neurotrophic factor related to NGF and BDNF. Science 247:1446-1451.

Maisonpierre PC, Le Beau MM, Espinosa RI, Ip NY, Belluscio L, De La Monte S, Squinto S, Furth ME, Yancopoulos GD (1991) Human and rat brain-derived neurotrophic factor and neurotrophin-3: gene structures, distributions, and chromosomal localization. Genomics 10 : 558-568.

Marsh HN, Scholz WK, Lamballe F, Klein R, Nanduri V, Barbacid M, Palfrey HC (1993) Signal transduction events mediated by the BDNF receptor gp $145^{\text {trkB }}$ in primary hippocampal pyramidal cell culture. J Neurosci 13:4281-4292. 
Merlio J-P, Ernfors P, Jaber M, Persson H (1992) Molecular cloning of rat trkC and distribution of cells expressing messenger RNA for members of the trk family in the rat central nervous system. Neuroscience $51: 513-532$.

Middlemas DS, Lindberg RA, Hunter T (1991) trkB, a neural receptor protein-tyrosine kinase: evidence for a full length and two truncated receptors. Mol Cell Biol 11:143-153.

Moghaddam B (1993) Stress preferentially increases extraneuronal levels of excitatory amino acids in the prefrontal cortex: comparison to hippocampus and basal ganglia. J Neurochem 60:1650-1657.

Nitsch R, Frotscher M (1991) Maintenance of peripheral dendrites of GABAergic neurons requires specific input. Brain Res 554:304-307.

O'Dell TJ, R. KE, Grant SGN (1991) Long-term potentiation in the hippocampus is blocked by tyrosine kinase inhibitors. Nature 353: 558560.

Phillips HS, Hains JM, Laramee GR, Rosenthal A, Winslow JW (1990) Widespread expression of BDNF but not NT3 by target areas of basal forebrain cholinergic neurons. Science 250:290-294.

Phillips HS, Hains JM, Armanini M, Laramee GR, Winslow JW (1991) BDNF mRNA is decreased in the hippocampus of individuals with Alzheimer's disease. Neuron 7:695-702.

Rocamora N, Palacios JM, Mengod G (1992) Limbic seizures induce a differential regulation of the expression of nerve growth factor, brain-derived neurotrophic factor and neurotrophin-3, in the rat hippocampus. Mol Brain Res 13:27-33.

Ruit KG, Osborne PA, Schmidt RE, Johnson EM, Snider WD (1990) Nerve growth factor regulates sympathetic ganglion cell morphology and survival in the adult mouse. J Neurosci 10:2412-2419.

Sapolsky RM (1986) Glucocorticoid toxicity in the hippocampus: reversal by supplementation with brain fuels. J Neurosci 6:2240-2244.

Sapolsky RM (1992) Stress, the aging brain, and the mechanisms of neuron death. Cambridge, MA: MIT Press.

Shors TJ, Seib TB, Levine S, Thompson RF (1989) Inescapable versus escapable shock modulates long-term potentiation in the rat hippocampus. Science 244:224-226.

Sloviter RS (1989) Calcium-binding protein (calbindin- $\mathrm{D}_{28 \mathrm{k}}$ ) and parvalbumin immunocytochemistry: localization in the rat hippocampus with specific reference to the selective vulnerability of hippocampal neurons to seizure activity. J Comp Neurol 280:183-196.

Sloviter RS, Valiquette G, Abrams GM, Ronk EC, Sollas AL, Paul LA,
Neubort S (1989) Selective loss of hippocampal granule cells in the mature rat brain after adrenalectomy. Science 243:535-538.

Sofroniew MV, Cooper ID, Svendsen CN, Crossman P, Ip NY, Lindsay RM, Zafra F, Lindholm D (1993) Atrophy but not death of adult septal cholinergic neurons after ablation of target capacity to produce mRNAs for NGF, BDNF, and NT3. J Neurosci 13:5263-5276.

Spillantini MG, Aloe L, Alleva E, De Simone R, Goedert M, LeviMontalcini R (1989) Nerve growth factor mRNA and protein increase in hypothalamus in a mouse model of aggression. Proc Natl Acad Sci USA 86:8555-8559.

Sutula T, Xiao-Xian H, Cavazos J, Scott G (1988) Synaptic reorganization in the hippocampus induced by abnormal functional activity. Science 239:1147-1150.

Taglialatela G, Angelucci L, Ramacci MT, Foreman PJ, Perez-Polo JR (1990) ${ }^{125} \mathrm{I}-\beta$-Nerve growth factor binding is reduced in rat brain after stress exposure. J Neurosci Res 25:331-335.

Takeda A, Onodera H, Yamasaki Y, Furukawa K, Kogure K, Obinata M, Shibahara S (1992) Decreased expression of neurotrophin-3 mRNA in the rat hippocampus following transicnt forebrain ischemia. Brain Res 569:177-180.

Takeda A, Onodera H, Sugimoto A, Kogure K, Obinata M, Shibahara S (1993) Coordinated expression of messenger RNAs for nerve growth factor, brain-derived neurotrophic factor and neurotrophin-3 in the rat hippocampus following transient forebrain ischemia. Neuroscience 55:23-31.

Uno H, Tarara R, Else JG, Suleman MA, Sapolsky RM (1989) Hippocampal damage associated with prolonged and fatal stress in primates. J Neurosci 9:1705-1711.

Watanabe Y, Gould E, McEwen BS (1992) Stress induces atrophy of apical dendrites of hippocampal CA3 pyramidal neurons. Brain Res 588:341-345.

Wooley CS, Gould E, McEwen BS (1990) Exposure to excess glucocorticoids alters dendritic morphology of adult hippocampal pyramidal neurons. Brain Res 531:225-231.

Zafra F, Castren E; Thoenen H, Lindholm D (1991) Interplay between glutamate and $\gamma$-aminobutyric acid transmitter systems in the physiological regulation of brain-derived neurotrophic factor and nerve growth factor synthesis in hippocampal neurons. Proc Natl Acad Sci USA 88:10037-10041.

Zafra F, Lindholm D, Castren E, Hartikka J, Thoenen H (1992) Regulation of brain-derived neurotrophic factor and nerve growth factor mRNA in primary cultures of hippocampal neurons and astrocytes. J Neurosci 12:4793-4799. 